\section{PEACE, ECOLOGY, AND RELIGION: EVOLUTION AND BUDDHISM'S EMPATHIC RESPONSE}

\section{David Jones $^{1}$}

\begin{abstract}
It has become increasingly vital to secure some purchase on effecting the requisite changes in the Western Worldview to reintegrate humanity with the natural world. Only two possibilities exist for this reintegration: an affirmation of the evolutionary process and the development of human predispositions that intimately relate individuals to other lives. Such reintegration becomes possible only when humanity re-realizes its animality. This paper argues that these changes are vital to defining peaceful coexistence with not only animals and their environs, but within the human realm as well. By casting the idea of peace in the light of ecological thinking and the hope for creating sustainable environments, a more positive approach to defining peace can be made. Such a definition can lead to designing human habitats, food production systems, and the utilization of natural resources in more ecologically sustainable ways. Such designs and utilizations are known as "permaculture," a position advocated in this paper because it focuses more on the active roles which humans take in their environments. Such a way of thinking moves away from the ethical environmentalism of Stewardship, which
\end{abstract}

${ }^{1}$ Professor, Kennesaw State University, Atlanta, Georgia. focuses on two emotions: cast in the negative as pity and in the positive as respect. In either emotion, peace is seen as transcendently given in absolute terms. The alternative of Buddhism is presented as a philosophical way out of the conundrum of stewardship. This alternative in itself is not new-these ideas have been in circulation for almost three decades-but what is distinctive in what is advocated is the synthesis of philosophical and scientific ideas such as intimacy, immanence, animality, evolution, empathy, and compassion seen dialectically vis-àvis integrity, transcendence, stewardship, and pity and respect. ${ }^{2}$

In a letter written in 1899 to William T. Stead, Mark Twain remarked, "Peace by persuasion has a pleasant sound, but I think we should not be able to work it. We should have to tame the human race first, and history seems to show that cannot be done." Although history has demonstrated the difficulty of "taming" humanity, it has become increasingly vital to secure some purchase on effecting the requisite changes in those worldviews that either fail or overlook the ecological need of reintegrating humanity to its interconnectedness with the natural world. Interestingly, religion needs to take its cue

\footnotetext{
${ }^{2}$ I am grateful to the two anonymous reviewers for providing their criticisms and prompting me to become clearer in what I was advocating in my more synthetic approach. They correctly reminded me that most people who argue for stewardship do so not because they advocate pity, but rather respect. Such reminders forced me to see why empathy and compassion function much better as a basis for all ethics than do respect, which, following Nietzsche, I generally see more in terms of pity. I also wish to thank Manusya's Editor, Dr. Amara Prasithrathsint, for her consideration and thoughtfulness.
} 
from science, especially from the discipline of primatology and more specifically from the Japanese who were the first to really look scientifically at the study of primates as a way of affording us insight into the social dimensions of humans. It is not altogether surprising, as we will see, that the Japanese, coming from a more "intimacy-based" view of the self vis-à-vis an "integrity-base" sense, would be inclined to move in the direction of animals to understand humanity.

In his book Life of Japanese Monkeys (1969), Kawai Masao introduces the approach of kyokan, which means "feelone," and places an emphasis on empathy and an "objective" form of subjectivity; that is, researchers need to enter the group they are studying, develop trust, and become in essence one with the social group where natural behavior can then be observed directly. Others, such as David Watts, have found this method to be invaluable. This identification with animals is necessary in understanding how humanity needs to "tame" itself and develop appropriate attitudes and behaviors in order to stop its devastation of the planet and our species. Two combined scenarios present themselves at this point: 1) affirm the evolutionary process and 2) develop human karmic predispositions that intimately relate individuals to other lives. Such reintegration becomes possible only when humanity re-realizes its animality.

In what follows, this paper suggests that these changes are vital to defining peaceful coexistence with not only animals and their environs, but within the human realm as well. In addition, this paper explores the philosophical underpinnings of religions committed to transcendence and our reluctance to give up religious beliefs in light of scientific discoveries. The alternative of Buddhism is presented as a philosophical way out of our conundrum as is the requisite action to incorporate some of its tenets such as karma into our religious worldview. This alternative in itself is not new-these ideas have been in circulation for almost three decades - but what is distinctive in what follows is the synthesis of philosophical and scientific ideas such as intimacy, immanence, animality, evolution, empathy, and compassion seen dialectically vis-à-vis integrity, transcendence, stewardship, and pity and respect.

Definitions of peace are often cast in the negative: peace is a state without war and/or conflict. Such definitions presuppose that "to make peace" is to eliminate war or to somehow mitigate conflict. By casting the idea of peace in the light of ecological thinking and the hope for creating sustainable environments, a more positive approach to defining peace can be made, and this idea of peace will include justice not only for the human realm but also for the animal. Such a definition can also lead to designing human habitats, food production systems, and the utilization of natural resources in more ecologically sustainable ways. Such designs and utilizations in ecological thinking are known as permaculture:

Permaculture is about designing ecological human habitats and food production systems. It is a land use and community building movement which strives for the harmonious integration of human dwellings, microclimate, annual and perennial plants, animals, soils, and water into stable, productive communities. The 
focus is not on these elements themselves, but rather on the relationships created among them by the way we place them in the landscape. This synergy is further enhanced by mimicking patterns found in nature. ${ }^{3}$

The emphasis here focuses more on the active roles which humans take in their environments and the way we think about our so-called environs. Such a way of thinking moves away from the ethical environmentalism of Stewardship where pity is the primary and operative emotion; stewards lay their pity upon those less developed species who were created by a monotheistic God to serve human needs and wants; pity is the prevailing emotional modus operandi and peace is seen as transcendently given in absolute terms in this approach. The idea, however, is to move beyond stewardship and its

\footnotetext{
3 "A central theme in permaculture is the design of ecological landscapes that produce food. Emphasis is placed on multi-use plants, cultural practices such as sheet mulching and trellising, and the integration of animals to recycle nutrients and graze weeds. However, permaculture entails much more than just food production. Energy-efficient buildings, waste water treatment, recycling, and land stewardship in general are other important components of permaculture. More recently, permaculture has expanded its purview to include economic and social structures that support the evolution and development of more permanent communities, such as cohousing projects and eco-villages. As such, permaculture design concepts are applicable to urban as well as rural settings, and are appropriate for single households as well as whole farms and villages." ATTRA - National Sustainable Agriculture Information Service. "Introduction to Permaculture: Concepts and Resources." $<$ http://attra.ncat.org/attraub/perma.html $>$.
}

emotional consort, pity, towards a healthier and more intimate, immanent, and relational sense of self with the natural world. This process is one of learning to give the human back to the world from which it has emerged; this process means relearning our forgotten wisdom of belonging to the earth and sky.

We see how the realignment of the religious psyche to a more fundamentalist and literal religious understanding of the place and meaning of the human in the vast universe bemoans our crisis of faith in religions prone to such literalization. We have somehow lost our way when we believe the earth is 6,000 to 10,000 years old based upon convoluted interpretations of a literal reading of the original testament of the Abrahamic religious tradition, instead of the 4.5 billion year estimate based upon a variety of scientific considerations and methods such as radiometric dating, which is a technique used to date materials based on decay rates of naturally occurring isotopes in comparison to their current abundance. On the one hand, such scientific considerations convey to us the rates of evolutionary change on our planet; but, on the other hand, this data reveals to us in a religious sense our eternally temporal relation to all that is. But what is it about the human psyche that makes us so insecure in the face of the scientific and philosophical understanding we create in order to comprehend, appreciate, and affirm our place in the world? How did this insecurity arise?

Our current degeneration into fundamentalism and literalism is a setback to ecology, peaceful co-existence, and a sustainable life for human co-habitation on the planet. This is a profoundly religious challenge for our species and it points to the problem 
that almost all religion foreground in their diverse ways: the problem of the ego. As James Hillman has so aptly put it, "Literalism is an ego viewpoint; it means being locked into an ego. Ego psychology results from being trapped by the ego into its perspective: the other characters on stage are merely characteristics, projections of mine" (Hillman 1975: 48). Historically, with the advent of the ego came monotheism; or with the advent of monotheism, egoism was born through the literalization of all the many gods and goddesses into one economical God; this God was omniscient, omnipotent, and everything the human was not. An example of this is found surprisingly in the "East" (an often visited place for many Westerners for cures for their spiritual malaise and environmental problems) when the Rig Veda states in its movement from polytheism to its more monotheistic tendencies: "And let the others die away." And die away they did. As the other gods died away in our primitive past, a monocentric self and monotheistic God became the Other in its transcendence from the natural-we ourselves were animal-like but somehow not animal. The mystery of the world's "worlding," its ability to selforganize itself, came to be lost.

As Hillman continues, "Literalism prevents mystery by narrowing the multiple ambiguity of meanings into one definition. Literalism is the natural concomitant of monotheistic consciousness-whether in theology or sciencewhich demands singleness of meaning. Precisely this monotheism of meaning prevents mystery ..." (Hillman 1975: 149). Consequently, the singularity of Truth is born and is held out over the many truths of myths, which are discovered in their multilayered levels of meaning. Again, Hillman is on target when he writes, "Their tales and their figures move through phases like dramas and interweave one with another. Whether expressed as instincts or Gods ... [o]ne instinct modifies another; one tale leads to another; one God implicates another" (Hillman 1975: 148). Out of all the religions, the movement from myth to philosophy (from a mythic worldview to an institutionalized religious worldview with the need for philosophical justification and mooring of beliefs) would find its most logical development in Buddhism. Buddhism, with its karmic predisposition to connect lives into a great chain of mutually conditioning ensembles, akin to how tales interweave one with another, would escape Nietzsche's criticism of the quest for a singular Truth and one God that it is nothing but "a mobile army of metaphors, metonyms, and anthropomorphisms" (Kaufmann 1954: 46-7).

To understand how the West has arrived at its current crisis of faith, we need to take a brief excursion back to the early Greeks. For the early Greeks, the psyche, or soul, was seen as a multiplicity of centers for the psychic intervention of the gods and goddesses (Snell 1982, Dodds 1951). The human soul was characterized by its openness to the world and its personified characters: the animals, plants, and rocks. This tendency to personify and display an animistic sensibility imbued the natural world with soul - it gave personhood to all beings, animate and inanimate. More importantly, however, it provided a sense of belonging, awe, and worship of the world itself. Nature was divine and the human species was an integral part of nature's sacred unfolding, nature's lila, its dance and play. But by the time of Plato and Aristotle, forerunners of the Christian and Islamic sensibility of the human soul, 
the soul would begin its unification and separation from other selves and creatures of the world. When Socrates shifts philosophical contemplation from cosmogonic discussions to a teleological inquiry and asks, "What is the purpose, the goal, the end (the telos) of life?" something profound happens to our religious sensibility. The question now posed is really the question, "What is the purpose, the goal, the end of my life?" And once I ask this question, you (and everything else in the universe) are separate, different, and other from me. I become an essential self, and the hubristic tendency behind this essentialism is egoism.

Even in Hinduism, which consciously fights egoism, ordinary life is seen as something that needs to be gone through so the soul, the introspective self, reaches a higher plane of being. Whether it is the atman realization of the Upanishads or the socially and politically oriented Mahatma Gandhi, the concentration is placed on the spiritual, not the natural. It is natural, however, for the individual soul to achieve union with Braham for "He is in us and yet above and beyond" (Iyer 1986-7: 28-29). Although seen and felt as natural, this transcendent naturalism takes one away from the earth, from its animals, for their lives are something we too need to work through for our own karmic purposes so we may attain moksha. This transcendence presupposes a certain kind of soul, one ultimately distinct from the mortal body; this atman is similar to the conception of the soul Plato put forth, which ultimately leads to the radical dualism of Cartesianism. Herein lies the problem: when one of the most prosperous countries in the world buys into this dualism, commits itself to global capitalism (itself a product of this dualism), and insists that the rest of the world follow its model, our attitude and subsequent actions and behaviors determine how we as humans will comport ourselves in the world we inhabit. We will be good ecological citizens when we wish, when we can, and when our economic systems provide us with the luxury to worry about those others than just ourselves.

This dualism and its companion economic system have its roots in the Platonic psyche. The soul for Plato was developed as tripartite with the rational part reigning over the spiritual and appetitive parts. Aristotle unifies the conception of the soul even more by giving this singular soul three powers: the vegetative (which we share with plants), the sensitive (which we share with animals), and the rational (which we humans alone possess). Even though humans would be forever linked to animal and plant life for Aristotle, we were, and indeed remain, superior to them for we are of a different kind. For Aristotle, it was a commitment to progress - to a great chain of being - that "all organisms can be put in a continuous line from the simplest to the most complex, from monad to man..." (Ruse 2005: 29). Although Aristotle's thinking is not straight away evolutionism, it was a necessary step in that direction, and evolutionary thinking had been wellestablished before him in the works of Anaximander, Heraclitus, Xenophanes, Democritus, Empedocles, and afterwards by Lucretius. When Platonic and Aristotelian thinking later gets mixed with Scholastic thinking, we're well on our way to Descartes' cogito ergo sum and its logical corollary of an encapsulated thinking self; this Cartesian self would be so unlike anything else in the universe, except, of course, God. If the ancient 
Greeks were to witness this development, they would be simultaneously entertained, bemused, and bewildered by the development of this hubristic posturing of a self not open to the controlling and conditioning forces of a personified and enlivened nature.

The outcome of this Cartesian way of thinking and being in the world has been devastating for the natural world, other creatures, and for the human ability to relate with each other. Evolutionary thinking, with its emphasis on natural selection, adaptation, mutation, mutualism, symbiosis, successful reproduction, and so forth is by definition immanent and seeks its meaning in and with nature. By adapting, a species is assiduously bound to its surroundings and internally grasps and appreciates, at least at some level, its world and those other creatures in it-for many of those other creatures will be necessary in developing symbiotic relationships for mutual survival even when they are defined by conflict, such as predator-prey relationships. Evolutionism binds one to the earth, its cycles, mutations, and relates the human to the animal; humanity is defined by its animality, for the human is fundamentally animal.

To be born from the animal is to be responsive like an animal - this is what it means to be an animal; to be responsive, it is necessary for one to acknowledge the other as not only real, but of value, whether that value is good or bad. To learn to be responsive is different from being responsible. Responsibility is the ethical product of a Cartesian self - an ego or encapsulated self that gives primacy to reason in order to locate the ethical. Thomas Kasulis refers in positive terms to this type of self as an "integrity self." As
Kasulis states, "Integrity tends to think of the world as something external to be managed through knowledge" (Kasulis 2002: 102). Integrity focuses on the "out there" through its use of "concepts, principles, and words" and connects to the world through an external relation between "the polarities of knower and known." In contradistinction to this self is the self of intimacy, and this will be the self of the anatman or anatta doctrine of Buddhism, where "intimacy ... tends to see the self and world as interlinking - the goal being to develop a sense of belonging with the world, feeling at home in it" (Kasulis 2002: 102). Intimacy will understand knowledge "to reside in the interface between self and world" (Kasulis 2002: 103). When applied to environmental issues, Kasulis' analysis becomes especially insightful:

For integrity's ethics, nature is that toward which we human beings have a responsibility. Our relationship to nature is external and bipolar insofar as our species is different from the rest of nature; we stand in a distinctive place visà-vis the natural world.... We act not only out of simple instinct but also conscious intentions allowing us to foresee the results of our actions. Hence, we are capable of responsibility [and] ... it is a human responsibility to be good stewards of the earth - to use our special capacities to heal the disrupted natural order [we have created].

(Kasulis 2002: 120-121)

Although Stewardship represents an adequate ethical position with regard to protecting the environment, it is necessarily philosophically flawed from 
the outset with its focus on responsibility instead of responsiveness. The prevailing emotion in stewardship (and ethics in general) is driven chiefly by feelings and emotions that lead to pity. Some would argue, especially those inclined to support stewardship as a viable ecological ethic, that respect, not pity, is the operative emotion in dealing with other species and their environments. This is the position of most Christian environmental ethicists, which should come as no surprise since it is through Christianity that the position of stewardship was born, and those who now wish to "green" God. ${ }^{4}$ Certainly within their contexts, these types of thinkers should be applauded for making the most of their situations and for at least being on the "right" side of the issue. And indeed in a practical sense they are allies to the Buddhist position. This position, however, has some inherent challenges that are difficult to overcome.

Following the lessons learned from Levinas about the other, respect of and for the other requires the treatment of the other as an equal, as having the same set of rights and obligations as the other of the other in a field of mutual reciprocity. But in the relationship of the human and nonhuman there is always a field of disparity between species, especially in systems of thought, often seen in the West, for humans are either created in the image of God or they are the only animals that possess rationality. Hence, I, this superior steward defined as a separate type of being, may respect those nonhuman beings, but the prevailing ethical emotion

\footnotetext{
${ }^{4}$ This is the position or tendency of thinkers such as Sean Mcdonagh (To Care for the Earth: A Call to a New Theology 1986, 1990); Ian Bradley (God is Green 1990); and Robin Attfield (The Ethics of Environmental Concerns 1990).
}

is for me to feel sorry for those others outside my scope of what it means to be a self. After all, I am undeniably a steward in a self-conscious position to recognize and self-reflect on my respect and care for them. I will act from my feeling sorry for them more frequently than from my respect for them; I will, in other words, pity those inferior others. Pity is the feeling of being superior through our pious egos, and by placing the human in the role of steward over the inferior-over the animal, the plant, the insect, and the rock-we are the special species created in God's image. I may be gracious in my application of responsibility, but I do so only because I am more advanced and superior enough to be gracious and loving toward those lesser others in the world. It is no surprise that in capitalistic systems we are good stewards when it is convenient to us. In times of downward dips in the economy and high unemployment, we will compromise that very integrity that constitutes us in order to survive the immediacy of our hard times. Likewise, I may respect those animals that are faster than me, stronger than me, better swimmers, and so forth, but I still do so from a position of superiority of intelligence and convenience. My respect to protect these creatures has its limits, namely when I can afford to be responsible for them. But there is an alternative to this kind of convenient stewardship.

To be responsive is to feel connected and be defined by this connection. Being defined in this connective way is to be a self of intimacy and its most radical and intimate formulation is given expression in the anatman doctrine where the self is an interbeing, the term coined by Thich Nhat Hanh to express the enhanced connectivity of a self that emerges from the dynamic 
play of the conditioning forces of the unfolding world. To realize this emergence and respond appropriately with selflessness to the world and its species is to be committed to the elimination of $d u k k h a$, uneasiness and suffering; such recreative activity is to be born anew into life's processes, and this renewal regenerates the self as an interbeing; such a giving over of the self is not only an affirmation of life, it is learning to make the suffering of others one's own. This kind of life is a life of compassion and requires the fundamental capacity to be empathic, and empathy curiously enough is essential to our nature, and the nature of animals. As Dōgen says, "To cultivateauthenticate all things by conveying yourself [to them] is delusion" (Kasulis 1981: 90); this act of "conveying oneself" is an act of pity, not of compassion.

What we find across the many forms of Buddhism from the historic Buddha to Dōgen to Thich Nhat Hanh is the affirmation of compassion. Respect is not absent from Buddhist beliefs or systems of thought, but the Buddhist emphasis is invariably placed on compassion. To extend ourselves through compassion is to suffer the pathos of life with all of the world's beings; it is to become an interbeing where we are held together by our subjectivity in the ecumenical web among other subjectivities; to extend ourselves through compassion is to lose the self through first learning to read the text of animals' suffering, which is to learn to be empathic to our nearest kin. This is the situation when the human first realizes its own animality. Buddhism and evolutionism promote this realization and affirmation of life by extending ourselves through compassion. This compassionate extension of self is not the same as pity (to feel sorry for the other or, to put it more positively, to respect the other as one of God's creatures through a deportment of difference) for to be compassionate, one must learn to suffer the pain of the other and learn to suffer with the other. To learn to suffer with the other is to learn to open up and develop the requisite skills for effective action. Such action is the goal of permaculture mentioned above, and it has everything to do with peace, peaceful coexistence, care, and love.

In Intimacy or Integrity, Kasulis writes that in the "intimacy orientation, ethics demands that I open myself to the other and accept the opening of the other to me" (Kasulis 2002: 118). Although all religions attempt in their own ways to accomplish this, in the final analysis some are more successful than others because of their original orientation to either intimacy or integrity and immanence or transcendence. In early Buddhism, for example, the morally functional terms "kusala' and "akusala" meant not "good" and "evil," but "skillful" and "unskillful" (Kasulis 2002: 118). We must learn to become skillful in our actions with respect to (not respect of or for) other species without our egos and pity getting in the way. Only then, can we somehow develop the necessary karuna, compassion, and it is through the employment of upaya, skillin-means, that this compassion is instantiated. The emotion or quality of respect as a foundation for an environmental ethics comes from the position of an integral self, a self of integrity that necessarily views itself as being separate and distinct from the other and defines itself by creating and establishing its integrity first and its relationship to the other as secondary. By definition, respect's focus is more on good and evil and less on developing the necessary ability to be skilled in one's 
relations with others; the right and wrong of western ethics, of integrity's ethics, are derived from the human capability to reason for we are the rational animal, as Aristotle remarked. Although rationality is an essential attribute of human nature, all ethics is based upon the emotion of empathy, that is, to have compassion for and suffer with others. My suggestion is that Buddhism's focus on and appreciation of skillful means is to have contextual flexibility and appropriateness, and this understanding is closer to the empathic root of ethics. In discussing the Buddha's thinking on upaya, John Schroeder states, "From the perspective of 'skillful means,' his ability to shift viewpoints shows that wisdom (prajna) is not bound by any single doctrine, practice, or metaphysical view, and exhibits the transformative intimacy of a Bodhisattva's love" (Schroeder 2001: 19). Such perspectival skillful means is what it means to be empty of self in Buddhist thought.

This idea of emptiness, or sunyata, is a lesson that can be learned from animals. Although we are beginning to visit these perspectives scientifically and sociobiologically, our visits are often without spirit, without the spirit of the Sâkyamuni Buddha, who attained enlightenment because he directly experienced the reality of suffering in a constantly changing world of conditionality as seen in the interdependent arising of all things - to see oneself as a part of this landscape requires empathy, to be in suffering with, not for the other. Such a feeling leads to compassion, an experience defined by similarity and resemblance, not by the difference of respect. Through this direct communion, the Buddha became an interbeing with all the other beings found in the earthly celestial landscapes of stones, plants, insects, animals. As Dōgen reminds us, "To cultivate-authenticate yourself by all things' presenting themselves - this is realization-satori" (Kasulis 1981: 90). The Buddha and his later "incarnations" of Nagarjuna, Kūkai, and Dōgen taught us the emptiness of being, and now, in their absence, the Buddha's diffused incarnation in the animals and plants around us points the way back into that very emptiness and back to our lost world. This is why we need to develop the skill-in-means to cultivate-authenticate ourselves by all things' presenting themselves to us. Our lessons for ethics come ultimately from animals and are found in our own animality.

If we take, for instance, the question of poverty and peace and ask whether respect for the other or empathy with the other underwrites the possible solution to poverty's elimination and the creation of peaceful coexistence, what will be our answer? For either of these goals, whether overcoming poverty or creating peace, it seems empathy and its accompanying compassion will always outdo respect. Respect will get us only so far in a world of growing populations and finite resources, especially if the rest of the world continues to desire the standard of living enjoyed by Americans and with Americans demanding the perpetual continuation of that standard for themselves. The carrying capacity of the world would need, it is predicted, to be six times what it is. This is known as "Six Earths" (Harris 2007). Will respect suffice in this regard? Empathy seems to be the more logical and preferred emotion to tap in order to address the issue of poverty and sustain peace. As beings, we are "hardwired," says Frans de Waal, the famous primatologist, to help those with whom we feel close: "We are hardwired to connect with those around us and to also 
resonate with them emotionally. It's a fully automated process" (de Waal 2005: 186). Compassion is a result of kin/family empathic ties and provides the basis for the necessary condition of cooperation needed to make societies work in any fashion, for in the family, comforting is natural and instinctual, even in younger members - the empathetic response is the strongest response humans have (de Waal 2005: 183). This empathetic response is, for de Waal, natural and connected not to respect, care, or even concern for the other, but to survival. Alluding to a number of studies on the matter, de Waal concludes, "In all of these studies, the likely explanation is not concern about the other's welfare, but distress caused by another's distress. Such a response has enormous survival value [for if] others show fear and distress, there may be good reasons for you to be worried, too" (de Waal 2005: 186). ${ }^{5}$ These conclusions are derived from the interface of animality and humanity. Such an understanding of the foundation of ethics suggests a much different type of discourse-that of responsiveness and intimacy.

There are profound differences between discourses of responsibility (integrity) and discourses of responsiveness (intimacy) and religious orientations of transcendence and immanence as there similarly are with applications of universal principles and maxims and the development of discourses of love and compassion coming from these respective pairs. As Kasulis reminds us, "We humans are part of nature, not separate from it" (Kasulis 2002: 121) and I might add, our closest relatives are the primates and these relatives of ours

\footnotetext{
${ }^{5}$ For these studies see Chapter five

"KINDNESS: Bodies and Moral Sentiments" in de Waal 2005.
}

display astonishing levels of empathy and compassion.

Although never developing a theory of evolution, the idea can be found in Buddhism in its early doctrine of interdependent arising (pratītyasamut pāda, Sanskrit; or paticcasamuppāda, Pali) and it is linked to individuals through the idea of karma. Interdependent arising is more a doctrine of conditionality than one of mere cause and effect.

With this as a condition, that arises

With this not as a condition, then that does not arise

All beings in the world are linked in an interdependent and mutually influencing web of conditioning factors. Because of this interdependence, the ontological status of a self (an atman) is rejected as nothing but a conventional configuration designed for convenience and utility in everyday life. This is known to be illusory and the source of attachment and delusion and is what Dōgen means when he talks about "cultivating-and authenticating all things by conveying oneself to them" instead of just realizing one's profound relation to every creature. The "conveying of oneself" is more than just realizing a relation to others - this would be what constitutes only respect-for it is to somehow feel the other in the depth of one's own being as many primates, dolphins, and elephants feel with each other and even for other species. Further, the delusory self of atman occludes the possibility of developing peaceful coexistence with members of our own species as well as other species and prevents affirmation of the dynamic harmony that has emerged through the mutual conditioning and progressive 
binomials such as day and night, and so on found in the world: dao's yin-yang. For Buddhists, all delusion can be traced back to the desire of and attachment to an essential self, and this is where Buddhism departs from its religious predecessor in India and from the Abrahamic religions of the West and Middle East that have had such success of conversion throughout the world and are perhaps eclipsed only by the advent of global capitalism. Any talk about the separate and essential being of anything is meaningless whether it be in the dualistic systems of thought found so resiliently in the West, the more monistic tendencies in the varieties of Hinduism, or in other forms of spirituality. Thus, all things are anicca, are conditioned by other things and are affirmed as transient, impermanent, insubstantial, and nonessential. In this regard, all things are empty (sunyata).

The idea of karma anticipated the need to connect human to human in and throughout time as well as to other species, especially to the animal, and establishes empathy and compassion as the primary ethical disposition. The linking and interdependence of all phenomena in the world is given expression in Indra's net, where multidimensional layers of intersecting fractally meshed webs contain infinite amounts of luminous multifaceted dewdrop jewels. Indra, ironically the god of war and weather, dynamic systems in themselves, weaves gossamer threads and at their intersections places pearls and jewels that reflect each other either in part or more holistically. This process goes on into infinity, and the individual pearls and jewels mirror in themselves the complexity of the vast universe through an array of self-similarity of all that is, was, and will come to be. Humans, too, find themselves in this complex network stretched out over a succession of lives that connect to each other and are conditioned by their interaction with members from their own species as well as others. Buddhist-like thinking is fundamental to our practice of ecology, and ecology needs to become our new form of religious thinking, our new spirituality. Religions such as Buddhism allow us to develop "a religion of ecology" for the $21^{\text {st }}$ century. To do so, we must relinquish our delusional, ego-besotted idea of self, of soul, and give soul back to the world and its species from which we have evolved and emerged. Such a proposition is more than just forfeiting the ego where we started in this essay; it is to relinquish completely and entirely the idea of a separate, autonomous, integral self because instead of empathy being the end point, the culmination of evolution or the product of rationality, it likely was the starting point that brought us together into functional societies and gave us some sort of peaceful coexistence with each other (de Waal 2006: 23). This proposition is more than a matter of survival; it is also a matter of peace.

In contradistinction to this Buddhist/ ecological sensibility is an even more problematic form of transcendence and integrity than pre-Buddhist Indian tendencies because this tendency is more prone to literalization and fundamentalism. The Abrahamic religious sensibility of a transcendent God - a God that is otherwill provide opportunities for making metaphysical and scientific claims beyond the scope of science. An example of the otherness of this God in relation to the topic of peace can be found in John 14: 27 "Peace I leave with you; my peace I give you. I do not give to you as the world gives. Do not let your hearts be troubled and do not be afraid" (New International 
Version 1984). Peace for the Christian is given; it is sent from heaven with its messenger who enters time through the union of divine spirit and human flesh. His intersection with time is from a transcendent beyond, a wholly other realm, and it is this intersection that spells out a certain ecological policy from God through his son for "I have told you these things, so that in me you may have peace. In this world you will have trouble. But take heart! I have overcome the world" (John 16: 33). In overcoming the world, the message is one of hope for the human species, not the animal, plant, insect, or rock. Isaiah (9:6-7) predicts this hope of transcendence when he states:

For to us a child is born, to us a son is given, and the government will be on his shoulders. And he will be called Wonderful Counselor, Mighty God, Everlasting Father, Prince of Peace. Of the increase of his government and peace there will be no end. He will reign on David's throne and over his kingdom, establishing and upholding it with justice and righteousness from that time on and forever. The zeal of the LORD Almighty will accomplish this.

But is this kind of hope for peace possible in a world with science? Is this hope to become good stewards in the image of the Good Shepherd, given from the great above, any longer possible in a world of war and conflict, economic injustice, and ecological devastation? Is this hope sufficient without willing ourselves as the human-animal back into the world? As Romans 12: 16 points out, if it is possible, "Live in harmony [peace] with one another. Do not be proud, but be willing to associate with people of low position. Do not be conceited." To be at peace with all men and women, it is necessary, and now imperative, to affirm a way of being in the world that can actually attain that peace without ego, hubris, self-delusion, and a sense of self that views itself as separate, distinct, and integral to itself. I suggest this new way of being is an old one and can easily be found in a Buddhist-like spirituality for it is in this wisdom and what we realize through science that we can become the species known as the "ecologically responsive Homo sapiens" (Kasulis 2002: 123). This is the species that can cultivate love, compassion, and peace unlike any other.

Ours is the species that can learn to overcome the conceit of pity for those of "low station"-for those less fortunate humans, those animals, plants, insects, and rocks. This is the species that can learn to overcome the conceit of pity through empathy and compassion, and learn to cultivate love and peace unlike any other. A "respect for" may be a necessary first step, but the next step should be to the animal empathy found within, for within this animality, our humanity is constituted.

\section{References}

ATTRA - National Sustainable Agriculture Information Service. "Introduction to Permaculture: Concepts and resources," Fayetteville, AR. November 26, 2006. <http://attra. ncat.org/attar-pub/perma.html $>$.

De Waal, Frans. 2005. Our Inner Ape. New York: The Penguin Group.

---. 2006. Primates and Philosophers: How Morality Evolved. Princeton: 
Princeton University Press.

Dodds, E.R. 1951. The Greeks and the Irrational. Berkeley: University of California Press.

Harris, R. J. 2007. "Nurturing Nature: Long-Term Management of Life's Evolution." December 28, 2007. $<$ junglephotos.com/wiki $>$.

Hillman, James. 1975. Re-Visioning Psychology. New York: Harper and Row Publishers.

Iyer, Raghavan. 1986-7. The Moral and Political Writings of Mahatma Gandhi. Oxford: Clarendon Press.

New International Version. 1984. International Bible Society. December 26, 2006. <http://www.biblegateway. $\mathrm{com} />$.

Kasulis, Thomas P. 1981. Zen Action/Zen Person. Honolulu: University of Hawai`i Press.

---. 2002. Intimacy or Integrity: Philosophy and Cultural Difference. Honolulu: University of Hawai i Press.

Kaufmann, Walter. 1954. The Viking Portable Nietzsche. New York: Viking Press.

Ruse, Michael. 2005. The EvolutionCreation Struggle. Cambridge: Harvard University Press.

Schroeder, John W. 2001. Skillful Means: The Heart of Buddhist Compassion. Honolulu: University of Hawai`i Press.
Snell, Bruno. 1982. The Discovery of the Mind. New York: Dover Publication.

Twain, Mark. 1/9/1899. "Letter to William T. Stead." November 26, 2006. $<\mathrm{http}: / /$ www/twainquotes.com/Peace. html>. 